\title{
Ecological impacts of non-native tree species plantations are broad and heterogeneous: a review of Brazilian research
}

\author{
MARCOS O. VALDUGA ${ }^{1,2}$, RAFAEL D. ZENNI ${ }^{3}$ and JEAN R.S. VITULE ${ }^{1,2}$ \\ ${ }^{1}$ Laboratório de Ecologia e Conservação, Departamento de Engenharia Ambiental, Setor de Tecnologia, \\ Universidade Federal do Paraná, Caixa Postal 19031, 81531-980 Curitiba, PR, Brasil \\ ${ }^{2}$ Programa de Pós-Graduação em Ecologia e Conservação, Universidade Federal \\ do Paraná, Caixa Postal 19031, 81531-980 Curitiba, PR, Brasil \\ ${ }^{3}$ Departamento de Biologia, Setor de Ecologia, Universidade Federal de Lavras, Caixa Postal 3037, 37200-000 Lavras, MG, Brasil
}

Manuscript received on August 13, 2015; accepted for publication on October 2, 2015

\begin{abstract}
Non-native tree plantations represent $7 \%$ of the world's forests and $1.24 \%$ of the Brazilian vegetation. Planted areas are expected to increase in the near future; thus, it is important to systematize existing knowledge on the ecological effects of plantations to aid forest management and biodiversity conservation. Here, we conducted a systematic review of the ecological literature associated with planted Pinus and Eucalyptus species in Brazil. We compared publication metrics with geographical distribution of species, ecosystems, biomes, studied taxa, and ecological impacts. We found 152 publications from 1992 to 2012. Number of publications positively correlated with area planted, number of plantations with forest certification, number of researchers, and richness of studied kingdoms. Most studies were in terrestrial ecosystems (92.1\%), the Atlantic Forest biome (55.3\%), and the kingdom Animalia (68.2\%). Most impacts of non-native tree plantations were negative (55.9\%), followed by positive $(27 \%)$, and mixed (17.1\%). Negative impacts were declines in species richness and abundance, seed bank diversity, and natural regeneration. Positive impacts were increase or mainteinance of seed bank diversity and natural regeneration. Mixed impacts were increases in abundance of native tree plantation pests. Taken together, results suggest forest management can help maintain biodiversity if it considers previous environmental conditions and integrates plantations with surrounding habitats.
\end{abstract}

Key words: biodiversity conservation, environmental changes, forest certification schemes, forest management, non-native woody plants.

\section{INTRODUCTION}

Large-scale introductions of non-native species are deemed one of the major agents of global environmental changes (Pereira et al. 2012). On the one hand, recent studies have showed that

Correspondence to: Jean Ricardo Simões Vitule

E-mail: biovitule@gmail.com non-native forest plantations (NNFP) can cause the extinction of species (Pereira et al. 2012) by favoring the occurrence of generalist and invasive species (Martin et al. 2012), by simplifying and homogenizing the structure of the environment, and by undermining ecosystem services (Araújo et al. 2010, Simberlof et al. 2010, Rundel et al. 
2014). Also, these plantations may affect water resources, altering its physical, chemical and biological characteristics (Scott 2005, Stenert et al. 2012). On the other hand, some other studies have showed that NNFP can promote the conservation of biodiversity and ecosystem services (Carnus et al. 2006, Brockerhoff et al. 2013) by maintaining native flora (Abreu et al. 2012) and fauna (Carrara et al. 2007). Based on the positive evidence, NNFP have been recommended for conservation of soil and water, for the production of biofuels, and as mitigation agents of climate change (Evans 2009).

In 2005, non-native forest plantations represented 7\% of the Earth's forest cover (Evans 2009), and future estimates suggest they might reach $20 \%$ by the end of the century (Brockerhoff et al. 2013). The majority of the increase in planted area has occurred mostly in megadiverse countries, such as Brazil, India and China (GIT 2009). In Brazil, massive investments resulted in an increase in the planted area from 400 thousand to 6.53 million hectares (mha) between 1965 and 2012 and are expected to reach nine million hectares in 2020 (ABRAF 2012). Most plantations use species from the genera Pinus (1.64 mha) and Eucalyptus (4.87 mha). NNFP are present in all Brazilian biomes and States, representing 1.24\% of the entire Brazilian vegetation cover, and adding great value for the Brazilian economy (ABRAF 2012). In order to mitigate the negative impacts and promote positive impacts of forest plantations, the majority of Brazilian NNFP have one or more forest certifications, such as FSC (Forest Stewardship Council) (BRACELPA 2012). FSC certification requires monitoring of the impacts of plantations on the native biota, proportionally to the scale, intensity and risk management (FSC 2012). The results found in the monitoring should be incorpored into forest management plans and published (FSC 2012).

Brazil is home to $\sim 20 \%$ of the world's biodiversity, has the highest number of endemic species globally (Forzza et al. 2012), and is recognized for the ecological (Evans 2009), social, and economic importance of NNFP (ABRAF 2012). In this context, it is important that all aspects of NNFP are consistently evaluated so that positive impacts may be accentuated and negative impacts be avoided or mitigated. Although largescale tree plantations have important implications for management and conservation of natural resources as well as biodiversity, a systematic review of the subject is lacking. Systematic reviews specify search criteria on a particular issue, using predefined protocols, aiming at reducing bias, allowing rigorous replication, and diagnosing gaps (Lowry et al. 2013). Systematic reviews provide high-quality results, identifying, appraising, and synthesizing all relevant studies on a particular topic (Uman 2011, Lowry et al. 2013, Mercuri et al. 2016).

Through a systematic review, this study sought (i) to identify which journals publish more studies involving Brazilian biodiversity and NNFP; (ii) to verify trends in the number of studies published regarding the increase in planted and FSC certified areas; (iii) to assess the number of studies in relation to Brazilian States, to the cultivated species, and to the number of researchers in each state; (iv) to learn which ecosystems and biomes are the most studied in forestry plantation areas; (v) to check which native organisms are the most studied in forestry plantation areas, and its relation to the estimated number of species in the studied kingdoms; (vi) to identify and quantify impacts these plantations are having on biodiversity; and (vii) to qualify and quantify the likely sources of the impacts.

\section{MATERIALS AND METHODS}

Our review was performed using the ISI - Web of Science (WoS). We searched all WoS databases for studies published between 01/01/1960 and $12 / 18 / 2012$ with the following string of terms: 
Topic $=($ pinus OR pine OR eucal?pt*) AND Topic $=$ ("south america*" OR bra?il OR neotropic*). For the first screening, we used the title and summary of the articles to filter out publications not related to the objectives of this study (e.g., studies reporting only abiotic parameters or growth increment). In a subsequent screening, we selected only studies that measured, mentioned, or assessed the ecological effects of NNFP on the biota. Studies outside of that context were also discarded (e.g., publications that reported measures of community structure only in plantation areas, lacking comparisons with data from natural conditions or other comparative control, and studies focusing exclusively on planted non-native species). For all articles that met all selection criteria, we extracted the following information: year of publication, journal, States where the study was performed, species planted, studied ecosystem (aquatic and/or terrestrial), biomes (following IBGE 2013), taxa (i.e., kingdom, phylum, or division of the studied native species) (Whittaker 1969, ITIS 2013, Stevens 2013), objectives, impacts of plantations, and sources of impacts. In the case of studies involving more than one State, ecosystem, biome, kingdom (e.g., Plantae and Animalia), or phylum, data was entered for all groups. If the study indicated more than one likely source of impacts (e.g., increasing richness with aging planting and use of species planted as a resource for native species), these were quantified individually. Thus, the sum of studies across all categories exceeds the number of articles found in the final search.

To identify which journals publish more studies on the influence of NNFP on Brazilian biodiversity in relationship to the total number of articles published in each journal, we used the methodology proposed by Braga et al. (2012); the method considers the amount of studies found in our search for a particular journal and the total number of articles published in the same journal to calculate the relative weight $(w)$ of each journal in publishing studies related to ecological aspects of NNFP. The calculation was performed as follows $w$ $=[n /(p \times e \times y)] \times 1000$, where $n$ is the total number of articles found in our search for each journal, $p$ is the sum of the number of articles published in the first issue of each year considered in the search (1960-2012), $e$ is the number of issues per year, and $y$ is the number of years considered in the WoS database search. For the analysis, we used only journals that had four or more publications in the search result for the period between 2004 and 2012. The 2-year impact factor of the journal (IF) was also considered in the analysis, and was obtained from the Journal Citations Reports (2013).

To analyze the influence of the increase in NNFP area and areas with FSC certification (FSC 2013) in publication rates, we grouped articles according to the year of publication. Because of the lack of specific data on planted areas for the period between 1992 and 2000, during which there was a decrease in planted area, a proportional reduction of $-1.5 \%$ per year on planted area since 1990 was applied, following estimates from ABRAF (2004). For the year 2012, we used the growth rate of plantations as in 2011 and added $0.1 \%$ on the area planted in relation to 2011, following data from ABRAF (2012). For FSC certification, we evaluated the increase in number of studies between 1996 and 2010, period for which official data of certified areas was available (BRACELPA 2012).

In order to verify if the distribution of the number of publications follows the spatial distribution of tree plantations, we grouped publications by State and cultivated species (e.g., Pinus spp. or Eucalyptus spp.), and then related the information with the total planted area for each genera across all States with official data on NNFP (FIRJAN 2009, ABRAF 2012). Grouping data by State was required because Pinus spp. plantations are concentrated in the States of the southern region whereas Eucalyptus spp. plantations are concentrated in other States (ABRAF 2012). We 
also evaluated the spatial dimension reached by the studies by calculating the ratio of hectares per study for the total planted area, the total area with FSC certification, and the areas planted with Pinus spp. and Eucalyptus spp.

To test the relationship between the number of studies found per State and the number of researchers based on them in 2012, we used data on number of researchers associated with the knowledge areas encompassed by this study, excluding unrelated areas (e.g., medicine and literature). Researcher data were provided by the Brazilian Coordination for the Improvement of Personal Higher Education (CAPES 2013).

To evaluate the proportion of studies on ecosystems (aquatic or terrestrial), biomes (IBGE 2013), and native organisms, we grouped native organisms into taxonomic groups following Whittaker (1969). The greatest taxonomic refinement was used a posteriori for the two most studied kingdoms, following the Integrated Taxonomic Information System (ITIS 2013), and the Angiosperm Phylogeny Website (Stevens 2013). To estimate the relationship between the numbers of studies found in each kingdom and the number of species in those realms, we used the data from Lewinsohn and Prado (2005).

We also evaluated the proportion of each type of impact that NNFP had on studied ecosystems, biomes, and kingdoms of native species. We considered impact as any change (i.e., fluctuations different than natural variations) in the structural and functional parameters of populations and communities of native taxa and ecosystem functions or services: richness, abundance, reproduction, growth, colonization, density or biomass of organisms, diversity of the seed bank or natural regeneration, biomass or microbial activity in the soil and leaf decomposition (ISO14050 2013). Thus, the impact could have a positive effect (e.g., increase or maintenance of the parameters listed above), a negative effect (e.g., decrease in any of the same parameters listed above) or a mixed effect (positive for one or some of the parameters and negative for one or some of the parameters). To qualify the impacts found and facilitate the understanding of the variations generated, we classified them according to their specificity. Impacts on reproduction, growth, colonization, density, and biomass of organisms were grouped as "population-level impacts." Impacts on the richness, relative abundance, diversity of the seed bank, and natural regeneration were grouped as "community-level impacts." Changes in biomass, mesofauna, microbial activity in soil, decomposition rates in aquatic ecosystems, biological pest control by native organisms, and leaf decomposition were grouped as "ecosystemlevel impacts." Then, based on the conclusion of the studies, we obtained the likely sources for the reported impacts, and quantified the respective proportions of each impact group.

\section{DATA ANALYSIS}

We conducted graphical analysis of correlation and Pearson correlation tests to exam the relationship between the IF and the number of published studies that matched our search criteria. The same tests were used to investigate the relationship between the number of studies and variation of spatial, temporal and interspecific areas with NNFP, certified by FSC, as well as between the numbers of researchers based on each State. Finally, we checked whether there was a relationship between the number of studies found in the analyzed kingdoms and the estimated number of species for each kingdom. For all correlations performed, data were tested for normality using the Shapiro-Wilk test and log-transformed where appropriate. We performed a Chi-square test to assess differences in the distribution of impacts between ecosystems, biomes and kingdoms. All analyzes were performed in the Origin Pro-8 software (OriginLab Corporation). 


\section{RESULTS}

The initial search resulted in 1,494 articles from which 330 passed the first screening. A total of 152 $(10.1 \%)$ articles met the inclusion criteria during the second and final screening. These studies were published in 66 journals, $8.5 \%$ of them being published in "Forest Ecology and Management," $5.2 \%$ published in the "Brazilian Journal of Soil Science," and $4.6 \%$ published in "Biodiversity and Conservation" (Fig. 1). The 63 remaining journals published less than $4 \%$ of the studies each. The highest relative weights $(w)$ were 1.16 for the "Brazilian Journal of Ornithology," 0.81 for the journal "Mammalia," and 0.69 for the "Journal of Tropical Ecology" (Fig. 1). The 63 remaining journals had $w<0.69$. The mean \pm standard deviation of the IF was $1.336 \pm 1.07$. The journal with higher IF was the "Journal of Applied Ecology" (IF = 4.7, $\mathrm{n}=2$ ), followed by "Conservation Biology" (IF = 4.355, $\mathrm{n}=1$ ), and "Perspectives in Plant Ecology, Evolution and Systematics" (IF $=4.158, \mathrm{n}=1)$. There was no relationship between IF and relative frequency of studies per journal.

All studies matching our criteria were published after 1992, and we detected a substantial increase in the number of publications after 2005
(Fig. 2). The seven-year period concentrated $82.2 \%$ of the studies found, correlating with the increase in NNFP area $(r=0.5, p=0.01)$. Also, a positive correlation was found between the number of studies published and the increase in FSC certified area $(r=0.7, p<0.001$, Fig. 3a), with a proportion of one study for every 37,000 ha of certified area.

Out of the 17 Brazilian States with NNFP, 14 had studies performed in their territories. Three States (Minas Gerais, São Paulo, and Rio Grande do Sul) held the majority $(65.7 \%)$ of the studies (Table I); $75 \%$ of the studies were conducted in areas planted with Eucalyptus spp. and covered 14 out of the 17 States that plant these species; $66.3 \%$ of the studies on Eucalyptus spp. were conducted in Minas Gerais, São Paulo, and Rio Grande do Sul, with the proportion of one study for every 46,800 ha of planted area (Table I). The remaining studies $(25 \%)$ were conducted in areas planted with Pinus spp. and in eight out of the 12 States growing pine tree plantations, with the majority of studies $(75 \%)$ being located in Rio Grande do Sul, São Paulo, and Paraná with a proportion of one study for every 28,500 ha of planted area (Table I). The Pearson correlation test showed a positive relationship between number of publications and area planted

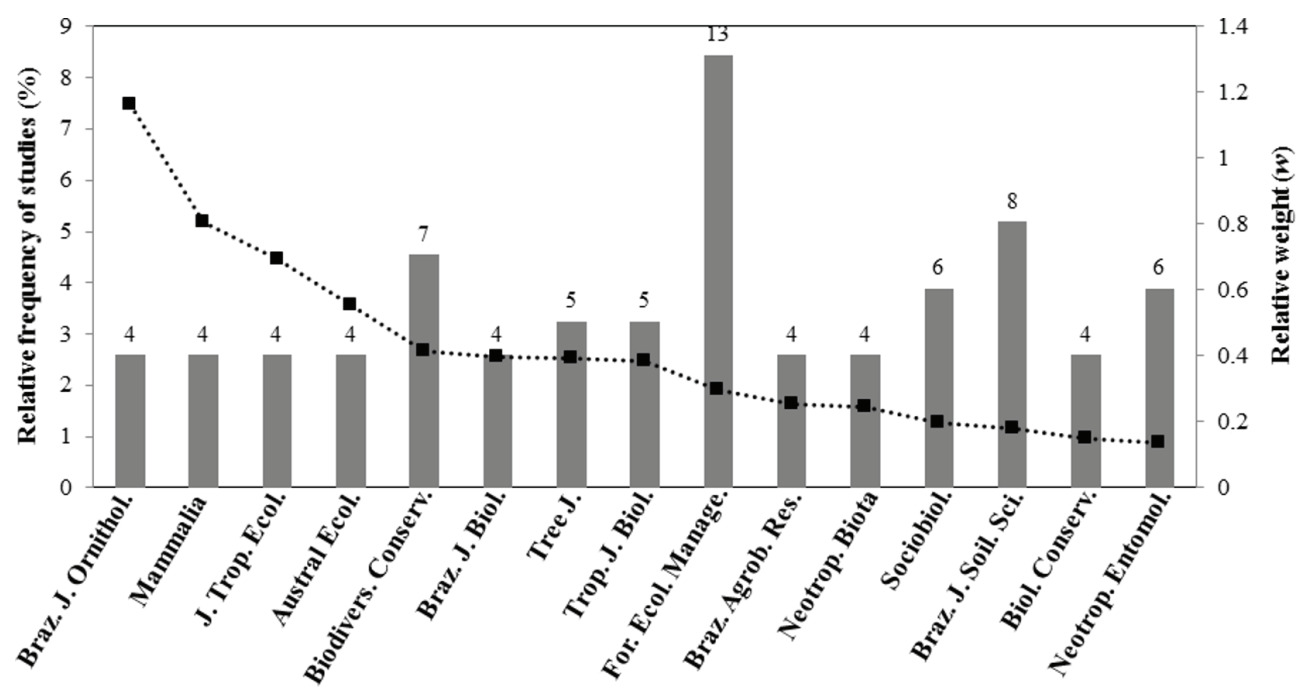

Figure 1 - Journals with four or more publications with ecological studies in NNFP. The grey bars represent the number of studies and the black squares represent the relative weight (w) of each journal. The numbers on the bars represent the number of studies in each journal. 
per State $(r=0.7, p<0.001)$, and between number of studies and area planted with Eucalyptus spp. ( $r$ $=0.6, p=0.009)$ (Fig. 3b) and Pinus spp. $(r=0.8$, $p=0.003$ ), repectively (Fig. 3c). We also found a positive relationship between number of studies published and number of researchers based on each State $(r=0.5, p=0.02)$ (Table I, Fig. 3d). Minas Gerais, São Paulo, and Rio Grande do Sul were the States with both the greatest production of studies and number of researchers (Fig. 3d).

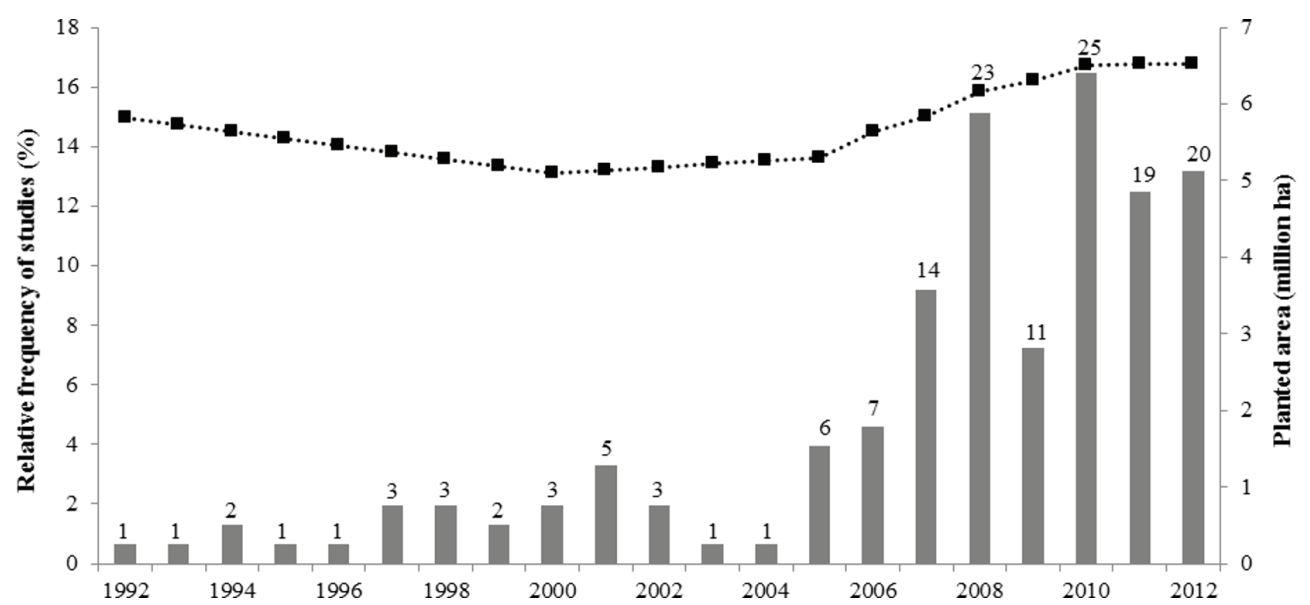

Figure 2 - Relative frequency of studies published and area planted with non-native tree species per year between 1992 and 2012. The grey bars represent the number of studies and the black squares represent the area planted with non-native tree species (million hectares) (ABRAF 2012). The numbers on the bars represent the number of studies in each year.

TABLE I

Number of studies in each Brazilian State (n). Where: EPA = area planted with Eucalyptus spp. (ha) (ABRAF 2012); NES = number of studies found for Eucalyptus spp. plantations; SPE = ratio of area planted with Eucalyptus spp. per study; PPA = area planted with Pinus spp. (ha) (ABRAF 2012); NPS = number of studies found for Pinus spp. plantations; SPP = ratio of area planted with Pinus spp. per study; RES = number of researches (CAPES 2013).

\begin{tabular}{lrrrrrrrr}
\hline State & n & \multicolumn{1}{c}{ EPA } & NES & \multicolumn{1}{c}{ SPE } & PPA & NPS & SPP & RES \\
\hline Amapa & 10 & 50,099 & 10 & $5,009.9$ & 445 & 0 & 0 & 49 \\
Bahia & 4 & 607,44 & 3 & 202,48 & 21,52 & 1 & 21,52 & 723 \\
Espirito Santo & 10 & 197,512 & 10 & $19,751.2$ & 2,546 & 0 & 0 & 193 \\
Goiás & 1 & 59,624 & 1 & 59,624 & 10,76 & 1 & 10,76 & 362 \\
Maranhão & 2 & 165,717 & 2 & $82,858.5$ & 0 & 0 & 0 & 111 \\
Mato Grosso & 0 & 58,843 & 0 & 0 & 0 & 0 & 0 & 318 \\
Mato Grosso do Sul & 3 & 475,528 & 3 & $158,509.3$ & 11,871 & 0 & 0 & 348 \\
Minas Gerais & 38 & $1,401,787$ & 35 & $40,051.1$ & 75,408 & 3 & 25,136 & 1,739 \\
Para & 11 & 151,378 & 11 & $13,761.6$ & 0 & 0 & 0 & 409 \\
Paraná & 9 & 188,153 & 5 & $37,630.6$ & 658,707 & 7 & 94,101 & 1,059 \\
Pernambuco & 1 & 13,541 & 1 & 13,541 & 0 & 0 & 0 & 576 \\
Piauí & 0 & 26,493 & 0 & 0 & 0 & 0 & 0 & 158 \\
Rio de Janeiro & 6 & 18,093 & 5 & $3,618.6$ & 156 & 1 & 156 & 1,569 \\
Rio Grande do Sul & 26 & 280,198 & 16 & $17,512.38$ & 164,086 & 21 & $7,813.6$ & 1,242 \\
Santa Catarina & 4 & 104,686 & 1 & 104,686 & 538,254 & 4 & $134,563.5$ & 367 \\
São Paulo & 33 & $1,031,677$ & 28 & $36,845.61$ & 156,726 & 8 & $19,590.7$ & 3,252 \\
Tocantins & 0 & 65,502 & 0 & 0 & 0 & 0 & 0 & 108 \\
\hline
\end{tabular}



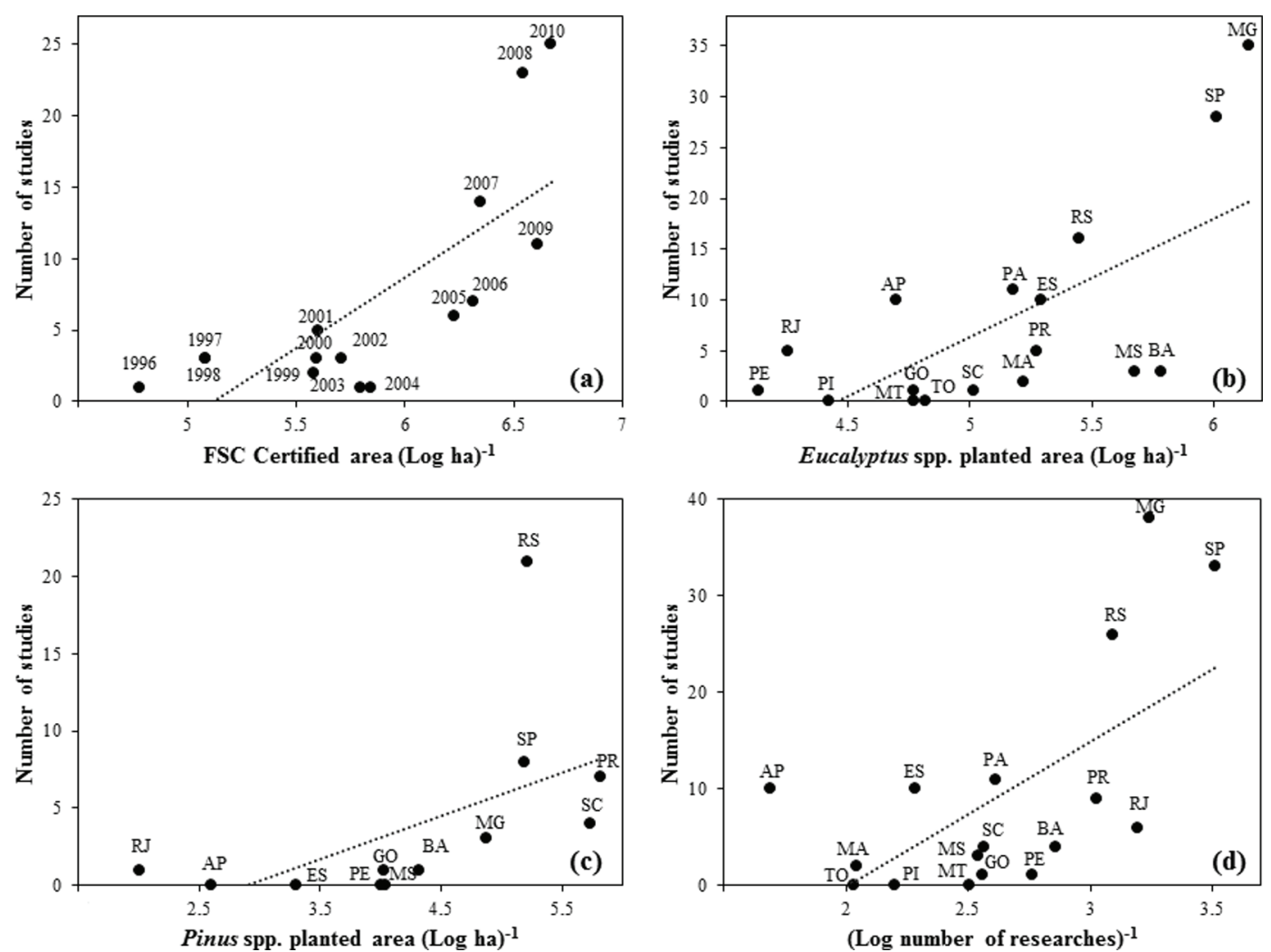

Figure 3 - Correlations (a) between number of studies and increase in number of FSC certified areas, (b) between number of studies and area planted with Eucalyptus spp. in each Brazilian State, (c) between number of studies and area planted with Pinus spp. each Brazilian State, and (d) between number of studies and number of researchers in each Brazilian State. Dotted lines indicate the lines of best fit. AP = Amapá; BA = Bahia; ES = Espírito Santo; $\mathrm{GO}=$ Goiás; MA = Maranhão; $\mathrm{MG}=$ Minas Gerais; $\mathrm{MS}=$ Mato Grosso do Sul; $\mathrm{MT}=\mathrm{Mato}$ Grosso; PA = Pará; PE = Pernambuco; PI = Piauí; PR = Paraná; RJ = Rio de Janeiro; RS = Rio Grande do Sul; $\mathrm{SC}=$ Santa Catarina; $\mathrm{SP}=$ São Paulo; $\mathrm{TO}=$ Tocantins.

The vast majority of the studies (92.1\%) were performed in terrestrial ecosystems, and only $7.9 \%$ were carried out in aquatic ecosystems (Table II). The Atlantic Forest was the most studied biome (55.3\% of the studies), followed by the Cerrado (28.3\%), the Amazon (7.2\%), the Pampas (6.6\%), and the Caatinga (2.6\%). Among the kingdoms, Animalia was the focus of $68.2 \%$ of the studies, followed by Plantae (18.2\%), Monera (7.8\%), and Fungi (5.8\%) (Table II). The Pearson correlation test showed a strong relationship between number of studies published and the estimated number of species in each kingdom $(r=0.9, p=0.01)$. In the kingdom Animalia, the phylum Arthropoda was the most studied (56.5\% of the studies), followed by the phyla Chordata (33\%), Mollusca (4.3\%), Annelida (3.5\%), Platyhelmintes (1.8\%) and Cnidaria $(0.9 \%)$. In the kingdom Plantae, the Angiospermae division was the most studied $(57.1 \%$ of the studies), followed by the Gimnospermae (20\%), Pteridophyta (17.1\%), and Bryophyta (5.8\%) divisions.

We found a prevalence of negative effects of NNFP on the community-level impacts in different ecosystems, biomes and native organisms studied, with the exception of the kingdom Plantae (Table II). There was an overall high frequency of results showing negative impacts among all the studies ( $\left.\mathrm{n}=152, \chi^{2}=17.1, d f=2, p<0.001\right)$, as well as per some individual groups: terrestrial ecosystems 
TABLE II

Number of studies (n) and relative frequency (\%) of the impacts on the population- (POP), community- (COM), and ecosystem-levels (ECO), and the percentual contribution on ecosystems, biomes and kingdoms studied. Ecosystems highlighted with * have higher frequency of negative impacts according the Chi-square test.

\begin{tabular}{lrrrrrrrrrrr}
\hline Impacts & \multicolumn{3}{c}{ Negative } & \multicolumn{3}{c}{ Positive } & \multicolumn{3}{c}{ Mixed } \\
\hline Total* & n & POP & COM & ECO & POP & COM & ECO & POP & COM & ECO \\
Ecosystem & 152 & 7.9 & 40.1 & 7.9 & 5.9 & 12.5 & 8.6 & 4.6 & 11.2 & 1.3 \\
Terrestrial* & & & & & & & & & & \\
Aquatic* & 140 & 7.1 & 38.6 & 7.1 & 6.4 & 13.6 & 10 & 5.0 & 11.4 & 0.7 \\
Biome & 12 & 16.7 & 50 & 8.3 & 0 & 0 & 0 & 0 & 25 & 0 \\
Atlantic Forest* & & & & & & & & & & \\
Cerrado & 84 & 8.3 & 42.9 & 2.4 & 8.3 & 9.5 & 10.7 & 4.8 & 10.7 & 2.4 \\
Amazônico & 43 & 11.6 & 27.9 & 4.7 & 2.3 & 18.6 & 11.6 & 7.0 & 16.3 & 0 \\
Pampa* & 11 & 9.1 & 45.5 & 9.1 & 0 & 36.4 & 0 & 0 & 0 & 0 \\
Caatinga & 10 & 10 & 70 & 10 & 0 & 0 & 0 & 0 & 10 & 0 \\
Kingdom & 4 & 0 & 50 & 0 & 0 & 25 & 0 & 0 & 25 & 0 \\
Animalia* & & & & & & & & & & \\
Plantae & 105 & 7.6 & 47.6 & 2.9 & 5.7 & 9.5 & 7.6 & 5.7 & 12.4 & 1 \\
Monera* & 28 & 3.6 & 28.6 & 7.1 & 7.1 & 28.6 & 10.7 & 3.6 & 10.7 & 0 \\
Fungi & 12 & 0 & 50 & 16.7 & 0 & 8.3 & 16.7 & 0 & 8.3 & 0 \\
\hline & 9 & 11.1 & 33.3 & 22.2 & 0 & 11.1 & 11.1 & 0 & 11.1 & 0 \\
\hline
\end{tabular}

(n $\left.=140, \chi^{2}=27.1, \mathrm{df}=2, p<0.001\right)$, aquatic ecosystems, $\left(\mathrm{n}=12, \chi^{2}=10.5, d f=2, p=0.005\right)$, Atlantic Rain Forest $\left(\mathrm{n}=84, \chi^{2}=16.9, d f=2, p\right.$ $<0.001)$, and Pampa ( $\mathrm{n}=10, \chi^{2}=8, d f=2, p=$ $0.02)$ biomes, and Animalia kingdom $\left(\mathrm{n}=105, \chi^{2}\right.$ $=13.2, d f=2, p<0.001)$. Of the studies reporting negative impacts, $65.9 \%(\mathrm{n}=56)$ cite some type of suboptimal forest management practices and the resulting reduced structural heterogeneity of the environment as sources of these impacts. Similarly, $24.7 \%(n=21)$ of the studies reported reduced rates of reincorporation of nutrients in the organic matter by mesofauna and microbiota decomposition (nutrient cycling), as well as decreases in the qualities of soil, water, and litter biomass. Another $4.7 \%(n=4)$ of the studies indicated a decrease in species richness of the seed bank along with the development of the rotation cycle. Finally, $4.7 \%$ of the studies $(n=4)$ reported invasion of surrounding areas of native vegetation by the planted species, the increased frequency of fungi diseases in native species, occurrence of hunting, and increased frequency of road kills and fires as generators of negative impacts.

Among studies reporting positive impacts, $53.4 \%(\mathrm{n}=22)$ mentioned maintenance of native vegetation in the understory of the plantations and connectivity among native remnants. For $27.6 \%$ (n $=11$ ) of the studies, the colonizing behavior of the cultivated species was a source of positive impact, along with maintenance of the seed bank, and 19\% $(n=8)$ of the studies reported the improvement of soil quality and increased fire protection.

In studies showing mixed impacts, $44.9 \%$ (n $=12$ ) cited as possible sources the maintenance of the carrying capacity of populations. $6.9 \%(n=2)$ pointed to an increase in richness of herbaceous species and a decrease in richness of climax species with aging plantations. 3.4\% $(\mathrm{n}=1)$ mentioned the use of cultivated areas by native species (i.e., 
foraging and shelter). Another $3.4 \%(\mathrm{n}=1)$ pointed to the role of native species in controling pests that attack NNFP. Finally, $41.4 \%(n=10)$ of the studies did not define the sources of impacts.

\section{DISCUSSION}

For over a century Brazil has been cultivating NNFP (Shimizu 2006). However, the interest in understanding the influence these plantations have on the biota is recent, even though it has grown substantially in the past decade, as shown by our results. The increased interest in understanding the impacts caused by the large-scale introduction of non-native species on ecosystems and loss of biodiversity (Schlaepfer et al. 2011, Valéry et al. 2013, Vitule et al. 2012) might be the cause for the recent growth in studies in cultivated areas. The diversity and weight of the journals where publications on the studied subject were found show that knowledge of possible implications of NNFP on the biota can be favored by transdisciplinarity work (Crow 2010). The high frequency of publications in journals with low IF may decrease the influence of the studies on other research and on scientific thought (Pyšek et al. 2006, González-Alcaide et al. 2012), as well as potentially limit their dissemination to other sectors of society (Primack et al. 2009), which may impair managerial decision making.

The adoption of FSC certification appears to have had a positive influence in the number of studies per planted area. Our results show an increase in research intensity after the wide adoption of certification by forest companies, probably because of the obligation imposed by FSC for companies to monitor impacts of plantations (FSC 2012). Still, many studies are produced and kept within the reforestation companies, making it difficult for external researchers to access the data (Van-Kujik et al. 2009, Visseren-Hamakers and Pattberg 2013). The availability of nearby research centers, such as universities, can increase the number of studies in NNFP areas. According to our review, the number of researchers per State correlated with the number of studies published. Formal interactions between research centers and reforestation companies are of great importance for the production and dissemination of knowledge, besides the fact that the interaction results in reduced costs for research (Crow 2010, Laursen et al. 2011). We suggest that research produced by the companies to comply with forest certification standards should be published in indexed journals, thus increasing the knowledge on the influence of NNFP and the FSC on biodiversity conservation (Visseren-Hamakers and Pattberg 2013).

The terrestrial ecosystem has been the most studied, as in other studies with non-native species (e.g., Lowry et al. 2013). Factors that may have stimulated the development of studies in terrestrial ecosystems rather than aquatic ones are the large affected area, the direct impact of NNFP on the ecosystem, the greater ease of study (Lowry et al. 2013), the presence of flagship (Heywood 1996) or umbrella species (Wilcox 1984) that attract greater investment for research projects, or even the presence of species of economic interest (e.g., Ramos et al. 2008). Individually or combined, these factors may also have encouraged the highest concentration of studies in the Animalia and Plantae kingdoms, as our results show. Moreover, we expected the number of studies involving the aquatic ecosystem would be greater than what was recorded because NNFP affects hydric resources (Scott 2005) and cover a large number of watersheds (Price 2011). Furthermore, freshwater systems can be more sensitive to the influence of non-native species compared to marine or terrestrial systems (Cox and Lima 2006). The effects of NNFP on aquatic ecosystems must receive more attention if we are to fully understand the impacts and prevent biodiversity and ecosystem services losses like water supply.

The impacts described by the studies suggest that the effects of NNFP on biodiversity are 
contingent on the organism and the conditions within the plantations. Often, the responses of native organisms may depend on various factors that can alter the magnitude and characteristics of the impacts found, such as proximity to areas with native vegetation, protection from hunting, connectivity between patches of native vegetation (Mazzolli 2010), pattern or order of arrival of invasive species in the ecosystem (Simberlof and Vitule 2013, Dickie et al. 2014) or propagule pressure (Rundel et al. 2014). Negative impacts predominate when NNFP replace native vegetation, whereas positive impacts occur when NNFP replace degraded areas; a greater number of mixed impacts are found when NNFP replace agricultural areas (Meyfroidt and Lambin 2011).

The high proportion of negative populationand community-level impacts associated with NNFP is quite worrying. The effects of land use changes can decrease carrying capacity, genetic variability, and fitness of native populations (Reed 2005, Willi et al. 2006); while also increasing the number of species threatened with extinction and causing losses of ecosystem services (e.g., litter fall and leaf decomposition). The environmental simplification in NNFP was appointed as the main of negative impact (e.g. Lyra-Jorge et al. 2010, Martin et al. 2012). Generally, environmental simplification was related to empoverishment of the seed bank (Nobrega et al. 2009) and woody plant diversity (Scolari et al. 2010), resulting in an increase in abundance of generalist organisms (Gonçalves et al. 2008, Gheler-Costa et al. 2012) and native species considered pests in plantations (Zanuncio et al. 1998). Furthermore, the studies reported that biological invasions by the planted species were one of the sources of negative impacts (e.g., Rolon et al. 2011). Some biomes (e.g., Cerrado and Pampa) may be highly susceptible to invasions by some of the most common tree plantations (Abreu and Durigan 2011). The invasive potential can be related to a larger size of planted species in relationship to native vegetation (Pysĕk et al. 2014), to adaptations possessed by some tree species (Zenni et al. 2014), and to ecological and physiological characteristics of planted species (Zenni et al. 2013). For instance, P. eliotti Engelm. dominated and reduced the richness and abundance of native Cerrado vegetation after 22 years of establishment of commercial plantations of this species (Abreu and Durigan 2011). In coastal ponds in the Pampa biome, invasion of riparian vegetation by cultivated species increased the abundance of generalist macroinvertebrates (Stenert et al. 2012). Thus, invasions by forestry trees can jeopardize the stability of ecosystems, affect primary and secondary productivity, and biogeochemical cycles (Simberlof et al. 2010, Rundel et al. 2014, van Wilgen and Richardson 2014).

Despite the prevalence of negative impacts, positive interactions may play an important role in regulating ecosystems (Halpern et al. 2007) and the predominance of positive impacts in the kingdom Plantae should be valued. The positive effects we reviewed can be related to the use of previously degraded areas for the implementation of NNFP (ABRAF 2012). The ability of some non-native tree crops to colonize degraded areas may aid the restoration of these areas, increasing the diversity and abundance of secondary and climax species (Nobrega et al. 2008). Moreover, the legal requirements that ensure the presence of native vegetation between cultivated areas (Federal Brazilian Law 12,651 2012) increase the flow of native propagules, vegetation and the maintenance of seed bank within the plantations (Abreu et al. 2012).

\section{CONCLUSION}

In megadiverse countries such as Brazil, the establishment of new NNFP should be limited to degraded rather than more pristine natural areas. There is a need for greater efforts to improve our understanding of the ecological implications of 
NNFP, mainly in aquatic ecosystems and the soil biota. Also, the Amazon and Pampa biomes lack research on the topic. In addition, the elaboration of forest management plans observing only current impacts should be discouraged, since impacts may be subtle and change over time (e.g., Simberloff and Vitule 2013). The results of studies in planted areas should support the development and implementation of more sustainable forest management plans that explicitly address the maintenance of native biodiversity within and between NNFP, thus reducing environmental simplification, encouraging connectivity between fragments, and the permanence of native species. Taken together, our results demonstrate the importance of conducting an efficient forest management. The concept of forest management is dynamic and includes the maintenance of complexity and landscape heterogeneity, connectivity, diversity, and ecological functions (e.g., Lindenmayer et al. 2006). Instead, our view is that forest management needs to balance environmental, economic, and cultural principles so that production solutions can be achieved through real innovation with more sustainability. Compliance with the abovementioned principles promotes the maintenance of ecosystem services and biodiversity for the future generations.

\section{ACKNOWLEDGMENTS}

We thank the members of the Ecology and Conservation Laboratory (LEC) of the Federal University of Paraná and Dr. A. Padial, who contributed significantly in preparing this manuscript. We thank Sara Kuebbing for English review, as well as anonymous reviewers that avalueted and improved our manuscript. Conselho Nacional de Desenvolvimento Científico e Tecnológico (CNPq) provided grants to J.R.S.V. and R.D.Z., and Coordenação de Aperfeiçoamento de Pessoal de Nível Superior (CAPES) provided a scholarship to M.O.V.

\section{RESUMO}

Plantações de árvores não nativas representam $7 \%$ das florestas do mundo e 1,24\% da vegetação brasileira. Essas áreas plantadas devem aumentar no futuro próximo; assim, é importante sistematizar o conhecimento existente sobre os efeitos ecológicos das plantações para auxiliar o manejo florestal e a conservação da biodiversidade. Aqui, realizamos uma revisão sistemática da literatura ecológica associada com espécies plantadas de Pinus e de Eucalyptus no Brasil. Nós comparamos as métricas de publicação com: a distribuição geográfica das espécies, os tipos de ecossistemas, os biomas, os taxa, e os impactos ecológicos. Encontramos 152 publicações entre 1992 e 2012. O número de publicações está positivamente correlacionada com a área plantada, número de plantações com certificação florestal, número de investigadores existente, e riqueza de reinos estudados. A maioria dos estudos foram em ecossistemas terrestres (92,1\%), no bioma Mata Atlântica (55,3\%), e no reino Animalia $(68,2 \%)$. A maioria dos impactos das plantações de árvores não nativas foram negativas $(55,9 \%)$, seguido pelo positivo (27\%) e mista (17,1\%). Impactos negativos foram declínios na riqueza e abundância de espécies, diversidade no banco de sementes e regeneração natural. Impactos positivos foram o aumento ou manutenção da diversidade banco de sementes e regeneração natural. Impactos mistos foram os aumentos na abundância de pragas de plantação de árvores nativas. Tomados em conjunto, nossos resultados sugerem que o manejo florestal pode ajudar a manter a biodiversidade se considerar as condições ambientais anteriores e integrar plantações com habitats nativos adjacentes.

Palavras-chave: conservação da biodiversidade, mudanças ambientais, sistemas de certificação florestal, manejo florestal, plantas lenhosas não-nativas.

\section{REFERENCES}

ABRAF - ASSOCIAÇÃo BRASILEIRA DE PRODUTORES DE FLORESTAS PLANTADAS. 2004. Anuário estatístico da ABRAF, $1^{\text {st }}$ ed., ABRAF, Brasília.

ABRAF - ASSOCIAÇÃo BRASILEIRA DE PRODUTORES DE Florestas Plantadas. 2012. Anuário estatístico da ABRAF, $1^{\text {st }}$ ed., ABRAF, Brasília.

ABreu RCR, Assis GB, Frison S, Aguirre A AND DURIGAN G. 2012. Corrigendum: Can native vegetation 
recover after slash pine cultivation in the Brazilian Savanna? Foreco 262: 1452-1459. For Ecol Manage 263: 1452-1459.

ABREU RCR AND DURIGAN G. 2011. Changes in the plant community of a Brazilian grassland savannah after 22 years of invasion by Pinus elliottii Engelm. Plant Ecol Divers 4: 269-278.

ARAÚJO ASF, SILVA EFL, NUNES LAPL AND CARNEIRO RFV. 2010. The effect of converting tropical native savanna to Eucalyptus grandis forest on soil microbial biomass. Land Degrad Develop 21: 540-545.

BRACELPA - BRAZILIAN PULP AND PAPER ASSOCIATION. 2012. Forest plantations: opportunities and challenges for the Brazilian pulp and paper industry on the path of sustainability / National Confederation of Industry, $1^{\text {st }}$ ed., BRACELPA, Brasília.

BRAGA RR, BORNATOWSKI H AND VITULE JRS. 2012. Feeding ecology of fishes: an overview of worldwide publications. Rev Fish Biol Fish 22: 915-929.

BROCKERHOFF EG, JACTEL H, PARROTTA JA AND FERRAZ SFB. 2013. Role of eucalypt and other planted forests in biodiversity conservation and the provision of biodiversityrelated ecosystem services. For Ecol Manage 301: 43-50.

CAPES - COORDENAÇÃO DE APERFEIÇOAMENTO PESSOAL DE NÍVEL SUPERIOR 2013. Dados estatísticos. Eletronic resource. $<$ http://geocapes.capes.gov.br/geocapesds/\#> (accessed March 2013).

CARnus JM, PARrotTA J, BrockerhofF EG, ARBEZ M, JACTEL H, KREMER A, LAMB D, O'HARA K AND WALTERS B. 2006. Planted forests and biodiversity. J For 104: 65-77.

CARrara LA, FARia LCP, ANTAS PTZ, MATOS JR, SARTÓRIO RC AND SCOPEL EV. 2010. Commercial Eucalyptus plantation as communal night roosts of parrots Amazona spp.: selective convergence. Rev Bras Ornitol 18: 49-54.

COX JG AND LIMA SL. 2006. Naïveté and an aquaticterrestrial dichotomy in the effects of introduced predators. Trends Ecol Evol 21: 674-680.

CROW MM. 2010. Organizing teaching and research to address the grand challenges of sustainable development. BioSci 60: 488-489.

Dickie IA, BENNETT BM, BURRows LE, NuÑEZ MA, PELTZER DA, PORTÉ A, RichARDSON DM, REJMÁNEK M, RUNDEL PW AND VAN WILGEN BW. 2014. Conflicting values: ecosystem services and invasive tree management. Biol Inv 16: 705-719.

EVANS J. 2009. Planted forests: uses, impacts, and sustainability, $1^{\text {st }}$ ed. International and Food and Agriculture Organization of the United Nations, Rome, $213 \mathrm{p}$.

FEDERAL BRAZILIAN LAW 12,651. 2012. Dispõe sobre a proteção da vegetação nativa. Diário Oficial da União, Brasília.
FIRJAN - FEDERAÇÃO DAS INDÚSTRIAS DO ESTADO DO RIO DE JANEIRO. 2009. Silvicultura econômica no Estado do Rio de Janeiro ${ }^{\circ}$ 5. Sistema FIRJAN, Rio de Janeiro.

FORZZA RC ET AL. 2012. New Brazilian floristic list highlights conservation challenges. BioSci 62: 39-45.

FSC - FOREST STEWARDSHIP COUNCIL. 2012. FSC Principles and criteria for forest stewardship. FSC-STD-01-001 (version 4-0). Eletronic resource. <http://www.fsc.org/ download.fsc-std-01-001-v4-0-en-fsc-principles-and-criteria-forforest-stewardship.181.htm $>$ (accessed December 2012)

FSC - Forest Stewardship Council. 2013. Fatos e números no Brasil e no mundo. Eletronic resource. $<\mathrm{http}: / /$ br.fsc.org/fatos-e-nmeros.188.htm $>$ (accessed February 2013).

GHeler-Costa C, Vettorazzi CA, PARdini R AND VERDADE LM. 2012. The distribution and abundance of small mammals in agro ecosystems of southeastern Brazil Mamm 75: 185-191.

GIT - GLOBAL EUCALYPTUS MAP. 2009. Eletronic resource. $<$ http://git-forestry.com/download_git_eucalyptus_map_ PT.htm> (accessed March 2013).

GONÇALVES AR, MARTINS RCC AND MARTINS IS. 2008. Soil seed bank from the understory of Pinus and Eucalyptus in the flona de Brasilia, Brazil. Cerne 14: 23-32.

GONZÁLEZ-ALCAIDE G, VALDERRAMA-ZURIÁN JC AND ALEIXANDRE-BENAVENT R. 2012. The impact factor in non-English-speaking countries. Scientometrics 92: 297311.

HALPERN BS, SILliman BR, OLDEN JD, BRUNO JP AND BERTNESS MD. 2007. Incorporating positive interactions in aquatic restoration and conservation. Front Ecol Environ 5: $153-160$

HEYWOOD VH. 1996. Global biodiversity assessment. United Nations Environment Programme. Cambridge University Press, Cambridge, $1152 \mathrm{p}$.

IBGE - Instituto BRAsileiro DE Geografia E ESTATÍSTICA. 2013. Mapa interativo dos biomas brasileiros. Eletronic resource. $<$ http://mapasinterativos. ibge.gov.br/indice/> (accessed March 2013).

ISO - INTERNATIONAL ORGANIZATION FOR STANDARDIZATION. 2013. Environmental management Vocabulary. Eletronic resource. $<$ https://www.iso.org/obp/ ui/\#iso:std:iso:14050:ed-3:v1:en> (accessed March 2013).

ITIS - INTEGRATED TAXONOMIC INFORMATION SYSTEM. 2013. Eletronic resource. $<$ http://www.itis.gov> (accessed January 2013).

JOURNAL CITATION REPORTS. 2013. Eletronic resource. http://admin-apps.webofknowledge.com/JCR/JCR?Poi ntOfEntry $=$ HomeandSID $=4 \mathrm{~B} 5 \mathrm{y} 28 \mathrm{OztWVfwOM} 3 \mathrm{WKE}$ (accessed July 2013).

LAURSEN K, REICHSTEIN T AND SALTERS A. 2011. Exploring the effect of geographical proximity and 
university quality on university-industry collaboration in the United Kingdom. Reg Stud 45: 507-523.

LEWINSOHN TM AND PRADO PI. 2005. Quantas espécies há no Brasil? Megadivers 1: 36-42.

LINDENMAYER DB, FRANKLIN JF AND FISCHERA J. 2006. General management principles and a checklist of strategies to guide forest biodiversity conservation. Biol Conserv 3: 433-445.

LOWRY E, ROLLINSON EJ, LAYBOURN AJ, SCOTT TE, AIELLO-LAMMENS ME, GRAY SM, MICKLEY J AND GUREVITCH J. 2013. Biological invasions: a field synopsis, systematic review, and database of the literature. Ecol Evol 3: 182-196.

LYRA-JORGE MC, RIBEIRO MC, CIOCHETI G, TAMBOSI LR AND PIVELLO VR. 2010. Influence of multi-scale landscape structure on the occurrence of carnivorous mammals in a human-modified savanna, Brazil. Eur $\mathrm{J}$ Wildl Res 56: 359-368.

MARTIN PS, GHELER-COSTA C, LOPES PC, ROSALINO LM AND VERDADE LM. 2012. Terrestrial non-volant small mammals in agro-silvicultural landscapes of Southeastern Brazil. For Ecol Manage 282: 185-195.

MAZZOLLI M. 2010. Mosaics of exotic forest plantations and native forests as habitat of Pumas. Environ Manage 46: 237-253

Meyfroidt P AND LAMBIn EF. 2011. Global forest transition: prospects for an end to deforestation. Annu Rev Environ Resour 36: 343-371.

Mercuri EGF, KumATA AYJ, AmARAL EB and Vitule JRS. 2016. Energy by Microbial Fuel Cells: Scientometric global synthesis and challenges. Renew Sust Energ Rev 65: 832-840.

Nobrega AMF, Valeri SV, Paula RC and Silva SA. 2008. Natural regeneration in forest remainders and reforested areas of "Mogi-Guaçu" river floodplain in Luiz Antonio Country, São Paulo, Brazil. Rev Árvore 32: 909-920.

Nobrega AMF, VALERI SV, PAUla RC, PAVANi MCMD AND SILVA SA. 2009. Seed bank of natural forest remainder and reforestation areas in a Mogi Guaçu river floodplain, Luiz Antonio country, São Paulo state, Brazil. Rev Árvore 33: 403-411.

PEREIRA HM, NAVARRo LMN AND MARTINS IS. 2012. Global biodiversity change: the bad, the good, and the unknown. Annu Rev Environ Resour 37: 25-50.

PRICE K. 2011. Effects of watershed topography, soils and use, and climate on base flow hydrology in humid regions: A review. Prog Phys Geogr 35: 465-492.

PrimaCK RB, ELlWOOd E, MiLler-RUShING AJ, MARrS R AND Mulligan A. 2009. Do gender, nationality, or academic age affect review decisions? An analysis of submissions to the journal biological conservation. Biol Conserv 142: 2415-2418.
PROMAB - PROGRAMA DE MONITORAMENTO AMBIENTAL EM MICROBACIAS. 2014. Eletronic resource. <http:// www.ipef.br/promab> (accessed March 2014).

PYŠEK P, JAROŠÍK V, PERGL J, MORAVCOVÁ L, CHYTRÝ M AND KÜHN I. 2014. Temperate trees and shrubs as global invaders: the relationship between invasiveness and native distribution depends on biological traits. Biol Inv 16: $577-$ 589.

PYŠEK P, RICHARDSON D AND JAROŠÍK V. 2006. Who cites who in the invasion zoo: insights from an analysis of the most highly cited papers in invasion ecology. Preslia 78: 437-468.

RAMOS VM, FORTI LC, ANDRADE APP, NORONHA NC AND CAMARGO RS. 2008. Density and spatial distribution of Atta sexdens rubropilosa and Atta laevigata colonies (Hym., Formicidae) in Eucalyptus spp. Sociobiol 51: 775781.

REED DH. 2005. Relationship between population size and fitness. Conserv Biol 19: 563-568.

Rolon AS, Rocha O AND MALTCHIK L. 2011. Does pine occurrence influence the macrophyte assemblage in Southern Brazil ponds? Hydrobiol 675: 157-165.

RUNDEL PW, DICKIE IA AND RICHARDSON DM. 2014. Tree invasions into treeless areas: mechanisms and ecosystem processes. Biol Inv 16: 663-675.

SCHLAEPFER MA, SAX DF AND OLDEN JD. 2011. The potential conservation value of non-native species. Conserv Biol 25: 428-437.

SCOLARI GO, ANDRADE GR, DiAs J, Moscogliato AV AND TOREZAN MD. 2010. Woody species richness and abundance in a reforestation of Pinus taeda L. and an Araucaria Forest in the center-east region of Parana State, Brazil. Semina - Ciênc Agr 31: 1361-1366.

SCOTT DF. 2005. On the hydrology of industrial timber plantation. Hydrol Process 19: 4203-4206.

SHIMIZU JY. 2006. Pinus na silvicultura brasileira. Rev Mad 99: 4-14.

SIMBERLOFF D et al. 2010. Spread and impact of introduced conifers in South America: Lessons from other southern hemisphere regions. Austral Ecol 35: 489-504.

SIMBERLOFF D AND VITULE JRS. 2013. A call for an end to calls for the end of invasion biology. Oikos 123: 408-413.

Stenert C, BaCCA RC, Moraes AB, Ávila AC AND MALTCHICK L. 2012. Negative effects of exotic pine invasion on macroinvertebrate communities in southern Brazil coastal ponds. Mar Freshw Res 63: 283-292.

STEVENS PF. 2013. Angiosperm Phylogeny Website. Eletronic resource. <http://www.mobot.org/MOBOT/research/ APweb/> (accessed March 2013).

UMAN LS. 2011. Systematic reviews and meta-analyses. J Can Acad Child Adolesc Psychiatry 20: 57-59.

VALÉRY L, FRITZ H AND LEFEUVRE JC. 2013. Another call for an end of invasion biology. Oikos 122: 1143-1146. 
VAN WILGEN BW AND RICHARDSON DM. 2014. Challenges and trade-offs in the management of invasive alien trees. Biol Inv 16: 721-734.

VAN-KUIJK M, ZAGT RJ AND PUTZ FE. 2009. Effects of certification on forest biodiversity. Report commissioned by Netherlands Environmental Assessment Agency. Tropenbos International, Wageningen. $71 \mathrm{p}$.

VISSEREN-HAMAKERS IJ AND PATTBERG P. 2013. We Can't See the Forest for the Trees. The Environmental Impact of Global Forest Certification Is Unknown. GAIA 22: 25-28.

Vitule JRS, FREIRE CA, VAZQUeZ DP, NuÑEZ MA AND SimberlofF D. 2012. Revisiting the Potential Conservation Value of Non-Native Species. Conserv Biol 26: 1153-1155.

WHITTAKER RH. 1969. New concepts of kingdoms of organisms. Sci 163: 150-160.

WILCOX BA. 1984. In situ conservation of genetic resources: determinants of minimum area requirements. In: McNeely
JA and Miller KR (Eds), National Parks, conservation, and development: the role of protected areas in sustaining society. Smithsonian Institution Press, Washington D.C., p. 639-647.

WILLI Y, BUSKIRK JV AND HOFFMANN AA. 2006. Limits to adaptive potential of small populations. Annu Rev Ecol Evol Syst 37: 433-458.

ZANUNCIO JC, MEZZOMO JA, GUEDES RNC AND OLIVEIRA AC. 1998. Influence of strips of native vegetation on Lepidoptera associated with Eucalyptus cloeziana in Brazil. For Ecol Manage 108: 85-90.

ZENNI RD, BAILEY JK AND SIMBERLOFF D. 2014. Rapid evolution and range expansion of an invasive plant are driven by provenance-environment interactions. Ecol Lett 17: 727-735.

ZENNI RD AND SIMBERLOFF D. 2013. Number of source populations as a potential driver of pine invasions in Brazil. Biol Inv 15: 1623-1639. 